\title{
FIRST SUBSTANTIATED RECORD OF A LESSEPSIAN MIGRANT-THE DUSKY SPINEFOOT, SIGANUS LURIDUS (ACTINOPTERYGII: PERCIFORMES: SIGANIDAE), IN THE ADRIATIC SEA
}

\author{
Jakov DULČIĆ ${ }^{1 *}$, Branko DRAGIČEVIĆ ${ }^{1}$, Robert GRGIČEVIĆ ${ }^{1}$, and Lovrenc LIPEJ ${ }^{2}$ \\ ${ }^{1}$ Institute of Oceanography and Fisheries, POB 500, 21000 Split, Croatia \\ ${ }^{2}$ Institute of Biology, Marine Biology Station, Fornače 43, 6630 Piran, Slovenia
}

Dulčić J., Dragičević B., Grgičević R., Lipej L. 2011. First substantiated record of a Lessepsian migrantthe dusky spinefoot, Siganus luridus (Actinopterygii: Perciformes: Siganidae), in the Adriatic Sea. Acta Ichthyol. Piscat. 41 (2): 141-143.

\begin{abstract}
One specimen of the dusky spinefoot, Siganus luridus (Rüppell, 1829) ( $(+$, total length $=17.3 \mathrm{~cm}$, total weight $=87.61 \mathrm{~g}$ ), a lessepsian migrant, was captured in the Mljet Channel (Southern Adriatic, Croatian coast) on 15 November 2010. This is the second record of this species from the Adriatic, but first well documented and based on the captured specimen. First record occurred earlier in the Northern Adriatic, but was based solely on underwater observations.
\end{abstract}

Keywords: Siganus luridus, Mediterranean, Lessepsian species, new record, Adriatic Sea.

Since the opening of the Suez canal in 1869 , there has been an influx of Red Sea and Indo-Pacific organisms into the Mediterranean Sea, a phenomenon known as Lessepsian migration. During the past decades, 74 Lessepsian fish species have been recorded from the Mediterranean Sea (Golani 2010), while 12 from the Adriatic Sea (Lipej and Dulčić 2010).

In this paper we present a record and description of the dusky spinefoot, Siganus luridus (Rüppell 1829), the most recent Lessepsian migrant found in the Adriatic Sea. It is a littoral fish, living in rocky habitats with thick vegetation and is usually found in small groups of adults and large schools of juveniles (Golani et al. 2002). It originally inhabits the western Indian Ocean, from eastern Africa, Mauritius and Reunion Island to the Arabian (Persian) Gulf (Golani et al. 2002, Letourneur et al. 2004). This species migrated into the Mediterranean from the Red Sea via the Suez Canal and the first record dates back to 1956 from the coast of Israel (Ben-Tuvia 1964). Along with its congener-Siganus rivulatus - it became very common in most coastal areas of the eastern Mediterranean. It is speculated that the reason for the colonizing success of these two species is the occupation of unsaturated niche characterized by the scarcity of indigenous herbivorous fish, but also their greater adaptability and competitiveness over indigenous herbivorous salema, Sarpa salpa (L.), and partially herbivorous parrotfish, Sparisoma cretense (L.) (see Golani et al. 2002, Bariche et al. 2004). The westernmost $S$. luridus populations are reported in the north-east of Tunisia (Ktari-Chakroun and Bouhlal 1971), the island of Linosa in the Sicily Strait (Azzurro and Andaloro 2004), in Cape d'Orlando, northern Sicily (Castriota and Andaloro 2008), and in Sausset-les-pins, French coast (Daniel et al. 2009).

The specimen of $S$. luridus ( + , total length $=17.3 \mathrm{~cm}$, total weight $=87.61 \mathrm{~g}$ ) (Fig. 1) was caught in the Mljet Channel (southern Adriatic, Croatian coast) (lat $42^{\circ} 48^{\prime} 556^{\prime \prime} \mathrm{N}$, long $\left.17^{\circ} 30^{\prime} 35^{\prime \prime} \mathrm{E}\right)$ on 15 November 2010 with a trawl on the muddy bottom. This is the second record of this fish for the Adriatic Sea, but the first one documented on the basis of a captured specimen which allowed us to present its morphometric measurements (Table 1) and its meristic data. Meristic data are as follows: dorsal fin rays XIV+10; anal fin rays VII+9, pectoral fin rays 16; pelvic fin rays $\mathrm{I}+3+\mathrm{I}$; caudal fin rays 19 . Morphometric measurements are in agreement with those presented by Castriota and Andaloro (2008).

Body deep, ellipsoid and compressed laterally. Dorsal fin origin above pectoral fin base. First dorsal spine small, directed forward and embedded in skin. Posterior margins of dorsal and anal fins rounded. Caudal fin truncated. Origin of pelvic fin behind pectoral fin base, its inner spine connecting by membrane to abdomen. Head slightly concave above eyes with blunt snout. Mouth small with thick upper lip. Body dark brown with irregular whitish blotches, more pronounced in abdominal area. Dorsal-, pectoral-, and caudal fins yellowish with yellow transverse stripes in whitish area under eyes.

\footnotetext{
${ }^{*}$ Correspondence: Dr. Jakov Dulčić, Institut za oceanografiju i ribarstvo, POB 500, Šetalište Ivana Meštrovića 63, 21000 Split, Croatia, phone: (+385) 21 408 013, fax: (+385) 358 650, e-mail: dulcic@izor.hr
} 


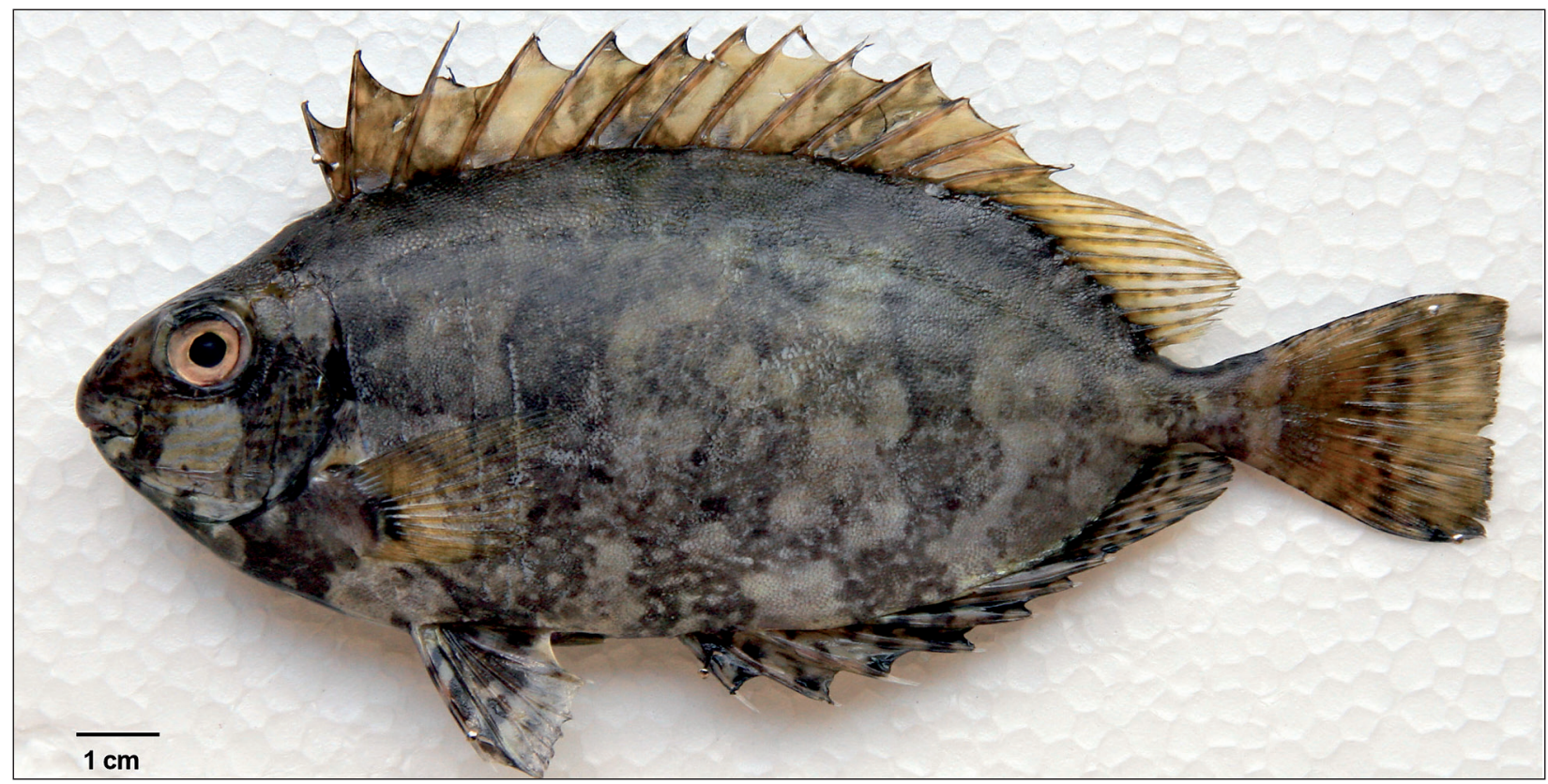

Fig. 1. Siganus luridus caught in the Mljet Channel (southern Adriatic, Croatian coast) ( + , total length $=17.3 \mathrm{~cm}$, total weight $=87.61 \mathrm{~g}$ )

The specimen is deposited in the Ichthyological Collection of the Institute of Oceanography and Fisheries in Split (code IOR-Siglur 1511).

The analysis in this study was based on the captured specimen while the first record of S. luridus in the Adriatic Sea was based on a set of observations, photographs, and videos taken on a single specimen at the locality of Bagno Ducale in the Marine protected area of Miramare (Trieste, northern Adriatic Sea) (Poloniato et al. 2010). Records from the Adriatic and one from the French coast (Daniel et al. 2009) constitute a considerable extension of the known distribution range of this species within the Mediterranean. The presence of S. luridus in the Adriatic could be a consequence of the "Adriatic ingressions" (periodically intensified influx of the Ionian water into the Adriatic which influences oceanographic parameters like salinity, temperature, transparency, as well as primary production) and oceanographic changes in the Adriatic Sea (Dulčić and Grbec 2000). The entrance of new alien organisms during the period of Adriatic ingressions was already observed (see Dulčić and Grbec 2000, Civitarese et al. 2010). Individuals from the Adriatic probably originate from some relatively close southern areas like Ionian Sea (Gulf of Patras) (Kaspiris 1976), Cretan waters (Golani et al. 2004), or Strait of Sicily (Azzurro and Andaloro 2004) where established populations of these fishes exist. This could be a sound explanation considering the hypothesis of Azzurro et al. (2006) regarding dispersal dynamics of this species, where they indicated that siganid larvae could be dispersed for up to $1000 \mathrm{~km}$. This could have also been facilitated by the impact of the bimodal oscillating system (BiOS) on the biogeochemistry of the Adriatic- and Ionian seas (Eastern Mediterranean) (Civitarese et al. 2010). A second hypothesis on the origin of the Adriatic specimens could be related to the anthropogenic transport of the species from some other area such as the eastern Mediterranean Sea or the Red Sea through ship-ballast waters. The area of capture is close to one of major cargo harbours in Croatian waters (Harbour Ploče) and this hypothesis remains plausible, as anthropogenic transport constitutes one of the major causes of introduction of exotic species, including teleost fish (Wonham et al. 2000). Recent report of an exotic dwarf flathead, Elates ransonnettii (Steindachner, 1876), from the Adriatic Sea evidenced a species introduction caused by the anthropogenic transport, probably by the ballast waters (Dulčić et al. 2010).

Table 1

Morphometric measurements of Siganus luridus caught in the Mljet Channel (November 2010)

\begin{tabular}{lcc} 
Measurement & Value [cm] & Relative value [\%] \\
\hline Total length (TL) & 17.3 & - \\
Standard length & 14.4 & $83.2 \mathrm{TL}$ \\
Pre-dorsal length & 3.1 & $17.9 \mathrm{TL}$ \\
Pre-anal length & 7.2 & $41.6 \mathrm{TL}$ \\
Pre-pectoral length & 3.4 & $19.6 \mathrm{TL}$ \\
Pre-pelvic length & 4.0 & $23.1 \mathrm{TL}$ \\
Dorsal fin length & 10.4 & $60.2 \mathrm{TL}$ \\
Anal fin length & 6.3 & $36.4 \mathrm{TL}$ \\
Pectoral fin length & 2.9 & $16.8 \mathrm{TL}$ \\
Ventral fin length & 2.3 & $13.3 \mathrm{TL}$ \\
Head length (HL) & 3.3 & $19.1 \mathrm{TL}$ \\
Interorbital width & 1.0 & $30.3 \mathrm{HL}$ \\
Eye diameter & 1.2 & $36.4 \mathrm{HL}$ \\
Preorbital length & 0.9 & $27.8 \mathrm{HL}$
\end{tabular}


The success of the $S$. luridus in the Mediterranean Sea has been attributed to its large eco-physiological plasticity. However, this present record still does not allow any confident comment regarding the success of this species in the Adriatic and whether an established breeding population exist in the area. In any event, the impact of possible successful colonization by this and other exotic fish species should be evaluated through future research.

\section{ACKNOWLEDGEMENTS}

Greatest thanks are expressed to fishermen Karlo Mlikota for providing us a specimen of the dusky spinefoot. We also thank to Ante Žuljević for taking a photo of specimen and to the Ministry of Science, Education and Sport of Republic of Croatia for financial support of the Project 001-0013077-0844.

\section{REFERENCES}

Azzurro E., Andaloro F. 2004. A new settled population of the Lessepsian migrant Siganus luridus (Pisces: Siganidae) in Linosa Island-Sicily Strait. Journal of the Marine Biological Association of the United Kingdom 84 (4): 819-821. DOI: 10.1017/S0025315404009993h.

Azzurro E., Golani D., Bucciarelli G., Bernardi G. 2006. Genetics of the early stages of invasion of the Lessepsian rabbitfish Siganus luridus. Journal of Experimental Marine Biology and Ecology 333 (2): 190-201. DOI: 10.1016/j.jembe.2005.12.002.

Bariche M., Letourneur Y., Harmelin-Vivien M. 2004. Temporal fluctuations and settlement patterns of native and Lessepsian herbivorous fishes on the Lebanese coast (eastern Mediterranean). Environmental Biology of Fishes 70 (1): 81-90. DOI: 10.1023/B:EBFI.0000022928.15148.75.

Ben-Tuvia A. 1964. Two siganid fishes of Red Sea Origin in the Eastern Mediterranean. Bulletin of the Sea Fisheries Research Station, Haifa 37: 3-9.

Castriota L., Andaloro F. 2008. First record of the Lessepsian fish Siganus luridus (Osteichthyes: Siganidae) in the Tyrrhenian Sea. Marine Biodiversity Records, 1, e11. DOI: 10.1017/S1755267205001223.

Civitarese G., Gačić M., Lipizer M., Eusebi Borzelli G.L. 2010. On the impact of the bimodal oscillating system (BiOS) on the biogeochemistry and biology of the Adriatic and Ionian seas (Eastern Mediterranean). Biogeosciences 7 (12): 3987-3997. DOI: 10.5194/bg-7-3987-2010.

Daniel B., Piro S., Charbonel E., Francour P., Letourneur Y. 2009. Lessepsian rabbitfish Siganus luridus reached the French Mediterranean coasts. Cybium 33 (2): 163-164.
Dulćić J., Grbec B. 2000. Climate change and Adriatic ichthyofauna. Fisheries Oceanography 9 (2): 187-191. DOI: 10.1046/j.1365-2419.2000.00128.x

Dulčić J., Pallaoro A., Dragičević B., Stagličić-Radica N. 2010. First record of dwarf flathead Elates ransonnetii [sic] (Platycephalidae) in the Adriatic Sea. Cybium 34 (2): 222-223.

Golani D. 2010. Colonization of the Mediterranean by Red Sea fishes via the Suez Canal - Lessepssian migration. Pp. 145-188. In: Golani D., Appelbaum-Golani B. (eds.) Fish invasions of the Mediterranean: Change and renewal. Pensoft, Sofia.

Golani D., Orsi Relini L., Massuti E., Quignard J.-P. 2002. CIESM Atlas of Exotic Species in the Mediterranean. Vol. I. Fishes. CIESM Publishers, Monaco.

Golani D., Orsi-Relini L., Massuti E., Quignard J.-P. 2004. Dynamics of fish invasions in the Mediterranean: update of the CIESM Fish Atlas. Rapport du Congrès de la Commission Internationale pour l'Exploration Scientifique de la Mer Méditerranée 37: 367.

Kaspiris P. 1976. New fish records from the Greek part of the Ionian Sea. Revue des Travaux de l'Institut des Pêches Maritimes 40: 627-628.

Ktari-Chakroun F., Bouhlal M. 1971. Record of Siganus luridus (Rüppel) in the Gulf of Tunisia. Bulletin de l'Institut national scientifique et technique d'Oceanographie et de pêche de Salammbô 2: 49-52.

Letourneur Y., Chabanet P., Durville P., Taquet M., Teissier E., Parmentier M., Quéro J.-C., Pothin K. 2004. An updated checklist of the marine fish fauna of Reunion Island, southwestern Indian Ocean. Cybium 28 (3): 199-216.

Lipej L., Dulčić J. 2010. Checklist of the Adriatic fish species. Zootaxa 2010 (2589): 1-92.

Poloniato D., Ciriaco S., Odorico R., Dulčić J., Lipej L. 2010. First record of the dusky spinefoot Siganus luridus (Rüppell, 1828 ) in the Adriatic Sea. Annales Series Historia Naturalis 20 (2): 161-166.

Wonham M.J., Carlton J.T., Ruiz G.M., Smith L.D. 2000. Fish and ships: Relating dispersal frequency to success in biological invasions. Marine Biology 136 (6): 1111-1121. DOI: $10.1007 / \mathrm{s} 002270000303$.

Received: 30 November 2010

Accepted: 1 March 2011

Published electronically: 30 June 2011 